\section{TECHNICAL FEATURES}

18 Metallic Superlattices: The Study of Materials at Length Scales from a Few to Hundreds of Angstroms

I.K. Schuller and H. Homma

Intercalation in Layered Materials M.S. Dresselhaus

Incorporation of Organic Dyes in Polymer/ Oxide Composites

E.J.A. Pope and J.D. Mackenzie

\section{INTERNATIONAL}

Highlights of the 1987
E-MRS Meeting

12 European Network Supports Interaction Among Materials Research Labs

44 Ceramics Research in
ISSUES

SSSC Annual Forum

Features Progress Reports on MSE Study

NAS Panel Calls for Reform of U.S. Export Controls

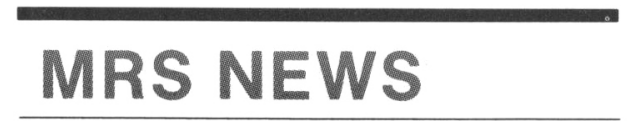

1. MRS Committees Announce 1987 Priorities

- Meeting Chairs Appointed 50 for 1988 MRS Spring Meeting

- 2 R. Krishnan Joins Editorial Board of MRS BULLETIN

Third Issue of 1987 Journal of Materials Research in Production

\section{SPECIAL}

\section{FEATURE}

14 Science Writers and Writing:
The Inside Scoop

\section{DEPARTMENTS}

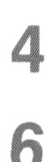

Material Matters

6 Research/Researchers

11 Editor's Choice

12 From Washington

13 Research Resources

53 Obituaries

54 Short Course News

55 Book Reviews

58 Calendar

Classified

60 Posterminaries

ON THE COVER: A montage of recent science writing about superconductors. For some insights into the process behind such articles, see "Science Writers and Writing: The Inside Scoop" on p. 14.

Photo courtesy of R.T. Jesih 


\section{MRS BULLETIN}

Editorial Board Chairman

E. N. Kaufmann

Lawrence Livermore National Laboratory

Associate Editor-Europe

A. Golanski

Centre National d'Études des

Telecommunications

CNS-RPT

Chemin du Vieux Chène BP 98

38243 Meylan Cedex France

(33) 76514067

Contributors:

M. Balkanski, J. Raloff, L.S. Millberg

Advertising and Circulation

M. E. Kaufold

(412) 367-3012
Editor

G. A. Oare

(412) $367-3036$

Assistant Editor

F. M. Wieloch

(412) $367-3036$

Design/Production

P. M. Gruden

(412) 367-3003

Editorial Assistant

J. Dininny

(412) $367-3036$

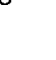

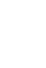

Road, Suite 327

\section{MRS BULLETIN EDITORIAL BOARD}
MINKO BALKANSKI
University of Pierre and Marie Curie
Laboratoire de Physique des Solides 4 Place Jussieu, Tour 13
75230 Paris Cedex 05, France
telephone: $336-25-25$
RICHARD B. FAIR
Vice President
Research Program Management
Microelectronics Center of North Carolina P.O. Box 12889
Research Triangle Park, NC 27709
telephone: (919) 248-1800
FRANK Y. FRADIN Director
Materials Science Division
Argonne National Laboratory
9700 South Cass Avenue
Argonne, IL. 60439
telephone: (312) 972-4925 SHU-EN HSU Director
Materials R\&D Center
Chung Shan Institute of
Science and Technology P.O. Box 1-26
Lung-Tan, Taiwan. China

Cable: CHUNSHANINST SHIMEN, TAIWAN

RALPH J. JACCODINE

Sherman Fairchild Professor

of Solid State Studies

Sherman Fairchild Laboratory 161 Lehigh University

Bethlehem, PA 18015

telephone: (215) 862-3950

HIROSHI KAMIMURA

Department of Physics

Faculty of Science

University of Tokyo

7-3-1 Hongo, Bunkyo-ku

Tokyo 113 Japan

telephone: 03-812-2111

telex: UTPHYSIC J23472

ELTON N. KAUFMANN (Chairman)

Lawrence Livermore National Laboratory P.O. Bo 808 L-350

Livermore, CA 94550

telephone: (415) 423-2640

R. KRISHNAN

Naval Chemical \& Metallurgical Laboratory

Naval Dockyard

Bombay 400023 , India

telex: 011-3192 NCML IN

JAMES L. MERZ

Associate Dean

for Research Development

College of Engineering

University of California

Santa Barbara, CA 93106

telephone: (805) 961-4446
SUSUMU NAMBA

Professor of Electrical Engineering

Faculty of Engineering Science

Osaka University. Toyonaka

Osaka, Japan 560

JULIA M. PHILLIPS

AT\&T Bell Laboratories Room 1E-431

600 Mountain Avenue

Murray Hill, NJ 07974

telephone: (201) 582-4428

EMANUELE RIMINI

University of Catania

Department of Physics 57 Corso Italia

I 95129 Catania, Italy

telephone: $37-70-61$

telex: 911554 INFNCT I

RUSTUM ROY

Materials Research Laboratory

Pennsylvania State University

University Park, PA 16802

telephone: (814) 865-3424

RICHARD L. SCHWOEBEL

Directorate 1800

Sandia National Laboratories

P.O. Box 5800

Albuquerque, NM 87185

telephone: (505) 844-9273

G. D. W. SMITH

University of Oxford

Department of Metallurgy

and Science of Materials Parks Road

Oxford OX1 $3 \mathrm{PH}$, England

TAKUO SUGANO

Professor of Engineering

Department of Electronic Engineering

University of Tokyo

7-3-1 Hongo, Bunkyo-ku

Tokyo 113 Japan

telephone: 03-812-2111, ext. 6675

C. W. WHITE

Solid State Division

Oak Ridge National Laboratory

Oak Ridge, TN 37831

telephone: (615) 574-6295

$$
\text { J. S. WILLIAMS }
$$

Royal Metbourne Institute of Technology

Microelectronics Tech. Center 124 Latrobe Street

Melbourne, Victoria 3000 , Australia telephone: 03-660-2459 XIE XIDE

Professor of Physics and President

Fudan University

Shanghai, China

67037 Strasbourg Cedex, France

(88) 286543

\section{ABOUT THE MATERIALS RESEARCH SOCIETY}

The Materials Research Society (MRS) is a nonprofit scientific association founded in 1973 to promote interdisciplinary goal-oriented basic research on materials of technological importance. Membership in the Society includes more than 4,800 scientists from industrial, government, and university research laboratories in the United States and more than 25 countries.

The Society's interdisciplinary approach to the exchange of technical information is qualitatively different from that provided by singledisciplinary professional societies because it promotes technical exchange across the various field s of science affecting materials development. MRS sponsors two major international annual meetings encompassing approximately 30 topical symposia, as well as numerous single-topic scientific meetings each year. It recognizes professional and technical excellence, conducts short courses, and fosters technical exchange in various local geographical regions through Section activities and Student Chapters on university campuses.

MRS is an Affiliated Society of the American Institute of Physics and participates in the international arena of materials research through associations with professional organizations such as European MRS.

MRS publishes symposia proceedings, the MRS BULLETIN, Journal of Materials Research, and other volumes on current scientific developments.

For further information on the Society's activities, contact MRS Headquarters, 9800 Mcknight Road, Suite 327. Pittsburgh, Pennsylvania 15237; telephone (412) 367-3003. 


\section{How important is a multi-technique ESCA system? Is important as your analysis.}

Multi-technique surface analysis has advantages: the capability to perform a complete sample haracterization using complementary techniques, fewer steps in sample hancling and reduced sample contamination.

ESCAL $A B$, the multitechnique system from VG Scientific, has even more, offering the widest range of analytical techniques-each with the highest performance-XPS, UPS, Auger, SIMS, LEISS, SEM/SAM-without having to remove the sample from the chamber. The $x$-ray monochromator gives higher resolution and lower radiation damage. And ESCALAB's small area XPS gives resolution in the range of 100 to 150 microns.
Through the use of VG's unique multi-user, multi-tasking 5000 DEC $^{-1}$ Data System, the power of ESCALAB is significantly enhanced.

Over 300 installations have experienced the quality results only a system as technological advanced as ESCALAB can provide. We invite you to them.

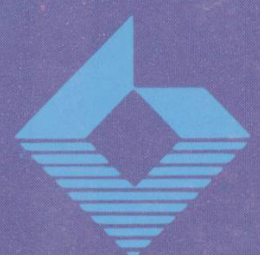

VG INSTRUMENTS Components for surface science and microscopy

A VG INSTRUMENTS GROUP COMPANY
USA. vG Instruments Inc., 32 Commerce Center, Cherry Hill Drive, Danvers, MA 01923. Tel, (617) 777-8034. VG Scientific Ltd.. Imberhorne Lane, East Grinstead, Sussex. England. Tel. (0)342-27211

WEST GERMANY. VG Instruments GmbH, Gustav-Nachtigal-Strasse 4, 6200, Wiesbaden. Tel. (6121) 713030 FRANCE. VG Instruments, 3 Rue du Marechal de Lattre de Tassigny, 78150 Le Chesnay. Tel. (1) 39555120. ITALY. VG Instruments Limited, Viale Dell'Assunta 101, 20063 Cernusco Sul Naviglio, Milano. Tel. (2) 9248808 THE NETHERLANDS. VG Instruments bV, PO Box 171, 1380 AD, Weesp. Tel. (2940) 80484

CHINA. VG Instruments, Room 7059, Xi Yuan Hotel, Erligou, Xijiao, Beijing. Tel, 890721 Ext 759.

HONG KONG. VG Instruments Asia Limited, GPO Box 217. Hong Kong. Tel. (5) 8613651.

JAPAN. Marubun Corporation, 8-1 Nihombashi Odemmacho, 2-Chome, Chuo-Ku, Tokyo 103, Japan, Tel. (3) 639986 